\title{
Maximum Power Point Tracking Using Fuzzy Logic Control for Grid-Connected Photovoltaic System \& Operation of PV Cells under Partial Shading Conditions
}

\author{
Subhash E. Apatekar ${ }^{1}$, Akireddy Shravankumar ${ }^{2}$, Ch. Anitha ${ }^{3}$ \\ Department of Electrical Engineering Fabtech Technical Campus Sangola Dist-Solapur
}

\begin{abstract}
Solar energy has been looked upon as a serious source of energy for many years because of the vast amounts of energy that are made freely available, if harnessed by modern technology. Electricity can be produced directly from photovoltaic (PV) cells which operate on photovoltaic effect. Each solar cell has a point at which the current (I) and voltage (V) output from the cell result in the maximum power output of the cell. Various approaches have been proposed to extract the maximum power from mismatched PV array. There is one new technique to optimize power from the mismatched PV array is reconfigurations. In this technique PV modules/cells in a PV array are continuously rearranged in series or parallel connections to facilitate the PV system to deliver maximum power even in shading conditions. In grid-connected photovoltaic (PV) systems energy is injected to the grid by keeping track of the maximum power point (MPP) of the panel, by reducing the switching frequency, and by providing high reliability. A fuzzy logic control based maximum power point tracking is used to obtain high efficiency and robustness of the solar photovoltaic (PV) power generation and establishes a dynamic model of grid-connected PV system by Matlab/Simulink environment which reflect the characteristics of the system accurately. A multilevel inverter topology is used to reduce total harmonic distortions in grid voltage and electromagnetic interference.
\end{abstract}

Keywords: Solar system, fuzzy logic control, PV cell, MPPT, Reconfiguration and I-V and PV characteristics

\section{Introduction}

Renewable energy uses energy sources that are continually replenished by nature-the sun, the wind, water, the Earth"s heat, and plants. Renewable energy technologies turn these fuels into usable forms of energy-most often electricity, but also heat, chemicals, or mechanical power. We often call renewable energy technologies "clean" or "green" because they produce few if any pollutants. World total installed power generation capacity stands at 5.4 Tera Watts per year and it is expected to increase to about 6.22 Tera Watts by 2020. The present installed power generation capacity of India is 229 Giga Watts and expected to increase to about $285 \mathrm{GW}$ by 2020 . The total installed power generation capacity includes the generation from both non-renewable and renewable energy sources. In India, the conventional sources share $87.55 \%$ of the total installed capacity and renewable sources share $12.45 \%$. Due to the fast depletion of fossil fuels and environmental degradation as a result of global warming, researchers and engineers are currently focusing their attention on the development of techniques to harness power from various alternate renewable energy sources such as solar power, wind power and geothermal, tidal power etc. to cover this increasing demand. Fig.1 shows the India"s Renewable energy Installed capacity. Solar photovoltaic is an environment friendly renewable source of energy which can help to meet the significant part of the increased demand of energy in the country [9].

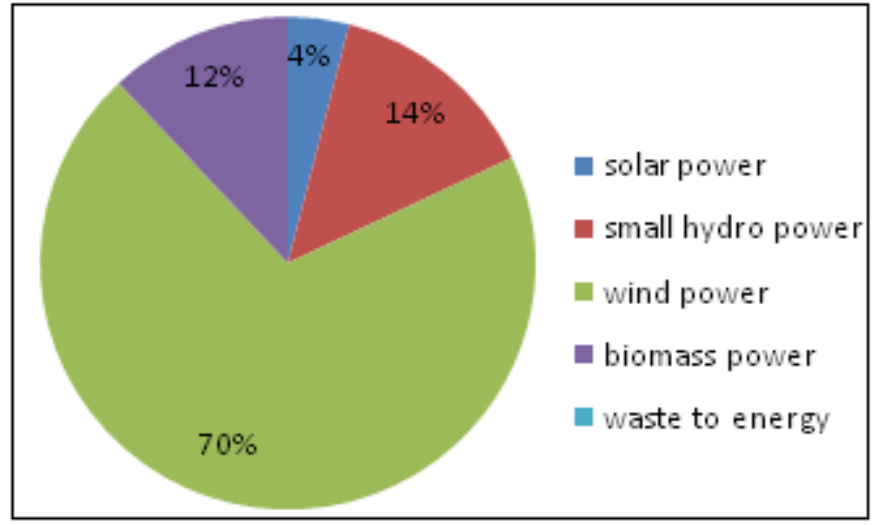

Figure 1: India ${ }^{e c}$ Renewable energy Installed capacity

Because of its location between the Tropic of Cancer and the Equator, India has an average annual temperature that ranges from $25^{\circ} \mathrm{C}-27.5^{\circ} \mathrm{C}$. This means that India has huge solar potential due to its geographical location in a tropical region, India is rich in terms of solar radiation and most part of the country receives good radiation for up to 250 to 300 days per year. India receives around 6,000 Trillion $\mathrm{kWh}$ per year of solar energy every year. This is far more than its total annual energy requirements. Due to these inherent advantages, the installations of PV array for power generation are expected to grow at a much faster rate in the country. At present the total installed capacity of solar PV generation in India is around 2.079GW. India has launched the Jawaharlal Nehru National Solar Mission (JNNSM) in 2009 according to which a target of $\sim 20 \mathrm{GW}$ has been fixed for 2020[8]. 


\section{International Journal of Science and Research (IJSR) \\ ISSN (Online): 2319-7064 \\ Index Copernicus Value (2015): 78.96 | Impact Factor (2015): 6.391}

\section{PV Cell}

The main part of the solar system is solar cell. Semiconductor solar cells are basically simple devices. Semiconductors are capable to absorb light and convert a percentage of the energy of the absorbed photons to electrical current. A solar cell can be thought of as a semiconductor diode which separates and collects electrons and holes and conducts the generated current in specific direction. The solar cell is delicately designed to efficiently absorb and convert light energy from the sun into electrical energy. Figure 2 shows the principle of a basic solar cell [9]. The PV cell physically represent in two way i.e. one diode model and two diode model. A PV cell has a voltage of just $0.5 \mathrm{~V}$. To meet the voltage/current demand according to a given application several solar cells are connected electrically in series or parallel to realize a PV module.

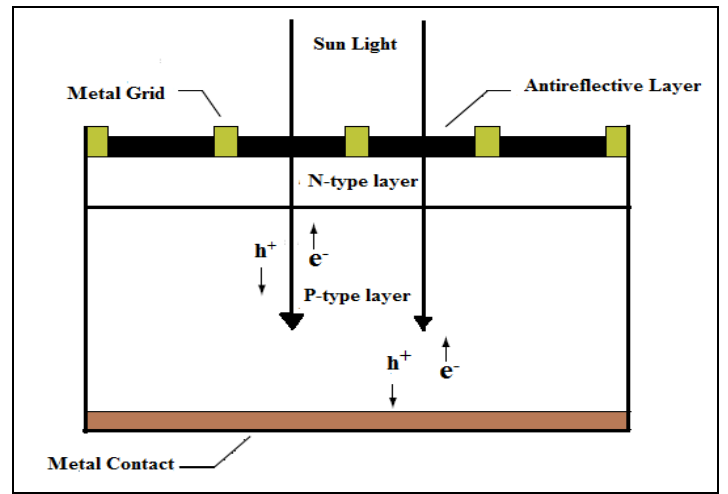

Figure 2: Principle of PV cell.

Several PV modules are connected in series according to the voltage requirement of the application to make a PV string. Several PV strings are connected in parallel according to the current requirement of the application to make a PV array.

\section{a) Type of PV Cell}

Solar cells can be created with a number of semiconductor materials. The most commonly used are the forms of silicon: Classification of PV cell is as shown in fig.3.

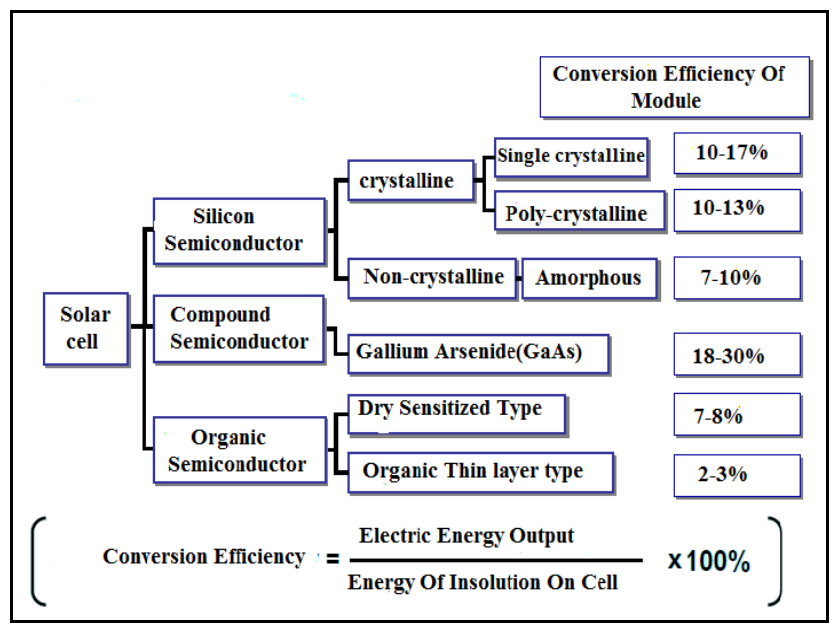

Figure 3: Type of PV cell

\section{Representation of PV Cell}

\section{A) One diode model}

The simplest version of one diode model is shown in Fig. 4. It consists of an ideal current source (representing the current generated by photons falling on the $\mathrm{p}-\mathrm{n}$ junction) in parallel with a diode. The output of the current source is constant for a particular temperature and radiation condition. The two main parameters of a PV cell are the short circuit current $\left(I_{S C}\right)$ and open circuit voltage $\left(V_{O C}\right)$. Under short circuit conditions $\left(R_{L}\right.$ $=0)$, the photon generated current $\left(I_{p h}\right)$ is equal to the short circuit current [1] [6].

By applying the Kirchhoff law to the node of the circuit reported in fig: 4 the current I produced by the photovoltaic module is obtained.

$$
\mathrm{I}=\mathrm{I}_{\mathrm{L}}-\mathrm{I}_{\mathrm{D}}
$$

Where:

$\mathrm{I}_{\mathrm{D}}=$ Diode current

$\mathrm{I}_{\mathrm{L}}=$ Photoelectric current related to a given condition of radiation and of temperature.

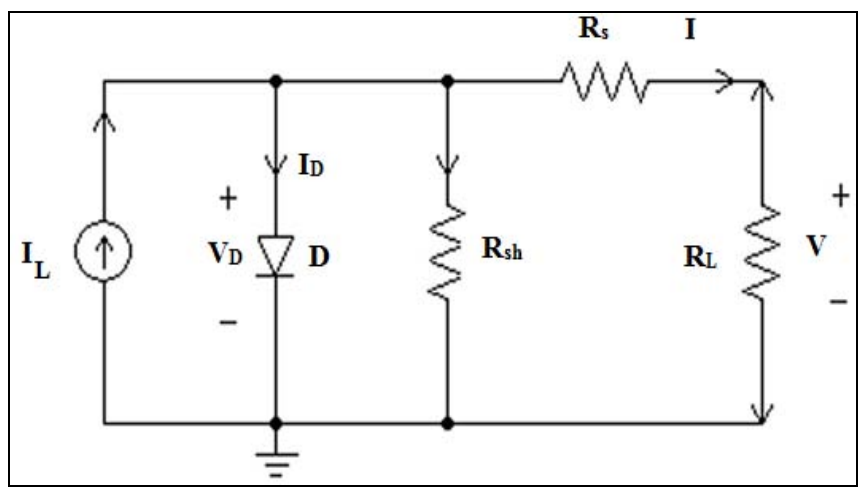

Figure 4: Physical representation of one diode model.

The $\mathrm{I}_{\mathrm{D}}$ diode current is given by the Shockley equation:

$$
\left.\mathrm{I}_{\mathrm{D}}=\mathrm{I}_{0}\left[\exp \frac{q(V+I R s)}{\gamma k T c}\right)-1\right]
$$

Where:

$\mathrm{V}=$ Output voltage $[\mathrm{V}]$;

Io $=$ Diode saturation current $[\mathrm{A}]$;

$\gamma=$ form factor which represents an index of the cell failing;

$R_{S}=$ Series resistance of the cell $[\Omega]$;

$q=$ electron charge $\left(1.602 \times 10^{-19} \mathrm{C}\right)$;

$\mathrm{k}=$ Boltzmann constant $\left(1.381 \times 10^{-23} \mathrm{~J} / \mathrm{K}\right)$;

$\mathrm{T}_{\mathrm{C}}=$ photovoltaic cell temperature $[\mathrm{K}]$

By substituting (2) into (1) the following equation is obtained which represents the I-V module characteristic curve under generic radiation and temperature conditions.

$$
\mathrm{I}=\mathrm{I}_{\mathrm{L}}-\mathrm{I}_{0}\left[\exp \left(\frac{q(V-I R s)}{\gamma k T c}\right)-1\right]
$$

The model proposed in (3) describes the working of a photovoltaic module under the hypothesis of knowing the values of $R_{S}, I_{0}$ and $I_{L}$. These values are definable as function of the data usually specified into the datasheet of the modules ${ }^{\text {ee }}$ 


\section{International Journal of Science and Research (IJSR) \\ ISSN (Online): 2319-7064 \\ Index Copernicus Value (2015): 78.96 | Impact Factor (2015): 6.391}

manufacturer $\mathrm{I}_{\mathrm{SC}, \mathrm{REF}}$ (short-circuit current under standard condition) $\mathrm{V}_{\mathrm{OC}, \mathrm{REf}}$ (load-less voltage under standard condition). In order to take into account the variation of the diode saturation current and the pv current when temperature and radiation change with respect to standard conditions, the model is completed with the following equations:

$$
\mathrm{I}_{0}=\mathrm{I}_{0 \mathrm{REF}}\left(\frac{\mathrm{Tc}}{\text { Tcref }}\right)^{3} \exp \left[\left(\frac{\mathrm{q} \mathrm{Eg}}{\mathrm{kg}}\right)\left(\frac{1}{\text { Tcref }}-\frac{1}{\mathrm{Tc}}\right)\right]
$$

Where:

$\mathrm{Eg}$ is the energy gap of the material with whom the cell is made (for the silicon it's 1 to $1.2 \mathrm{eV}$ );

$$
\mathrm{I}_{\mathrm{L}}=\left(\frac{G}{\text { Gref }}\right)[\text { Iref }+\mu(T c-\text { Tcref })] .
$$

$G$ is the radiation [W/m2]

Gref is the radiation under standard conditions [W/m2]

Iref is the photoelectric current under standard

$\mu$ is the temperature coefficient of the short-circuit condition.

\section{B) Two diode model}

One diode model (including losses) is sufficient to represent the characteristics of a PV cell. However, it doesn't take into account recombination in the depletion region of PV cells. Therefore, a second diode is added to further enhance accuracy of the characteristics representation at the expense of increased complexity. The second diode provides non-ohmic current path in parallel with the intrinsic PV cell as shown in Fig.5.

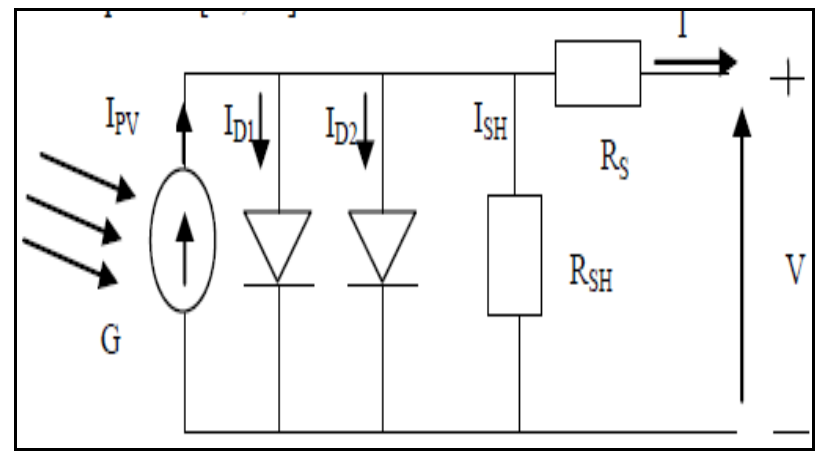

Figure 5: Physical representation of two diode model

\section{Modelling of PV Cell}

Complete Simulink model from above equations (1 to 5) of PV cell is shown in fig.6. Now we can get different output characteristics at different temperature and radiation levels by just changing the value of input parameters $\mathrm{T}$ and $\mathrm{G}$ [7] [10].

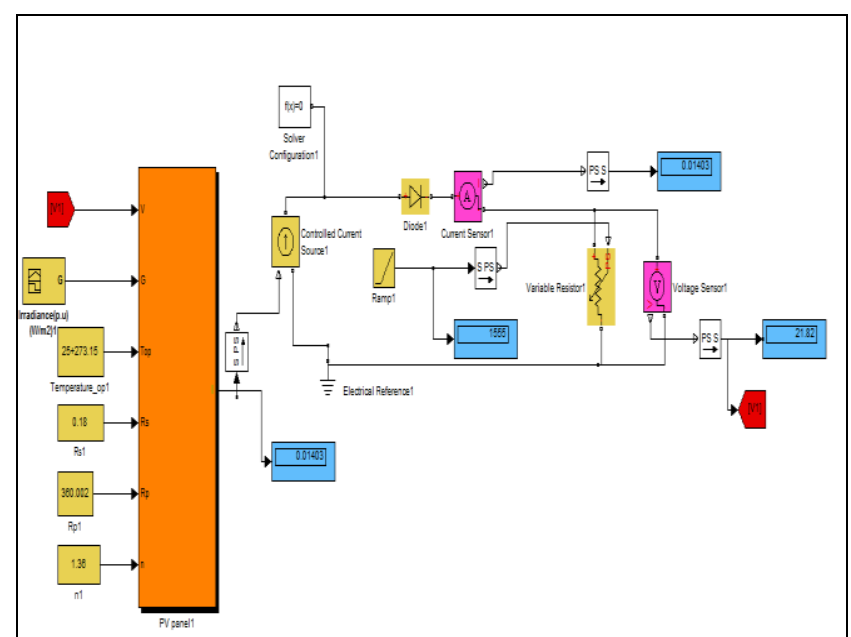

Figure 6: Simulink Model of PV cell

\section{Characteristics of PV Cell}

The basic characteristics which determining the most important parameters of a solar cell is I-V characteristic shown in fig. 7. From this curve we can read the parameters such as: short circuit current $I_{S C}$ and open circuit voltage $V_{O C}$. Moreover we can appoint the current $\mathrm{I}_{\mathrm{m}}$ and the voltage $\mathrm{V}_{\mathrm{m}}$. These two values define the point of maximum solar cell power on the I-V characteristic. When we have these values we can easily calculated more parameter, such as: the fill factor FF, the maximum power $P_{\max }$ or the cell efficiency $\eta$ [3] [8].

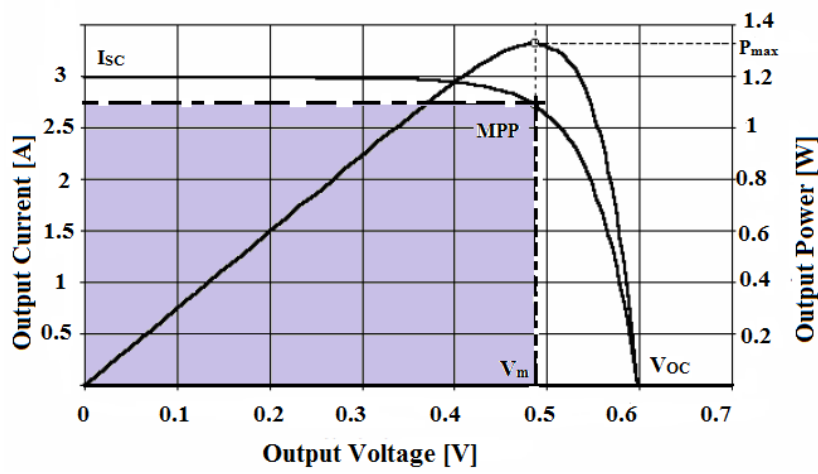

Figure 7: P-V characteristics

\section{Simulation Results}

The proposed model can provide calculated current, voltage and power relationships for different environmental conditions of solar radiations and ambient temperatures. These I-V and $\mathrm{P}-\mathrm{V}$ characteristics are produced by the proposed model for chosen PV array type through MATLAB/Simulink environment are shown in fig. 8 to 11 . 


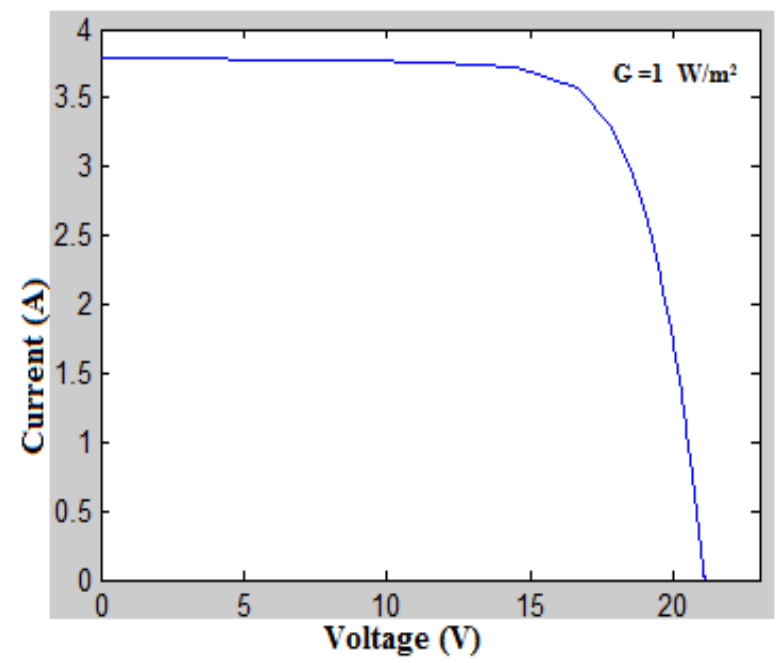

Figure 8: V-I Characteristics of a $P V$ cell at $G=1 \mathrm{~W} / \mathrm{m}^{2}$

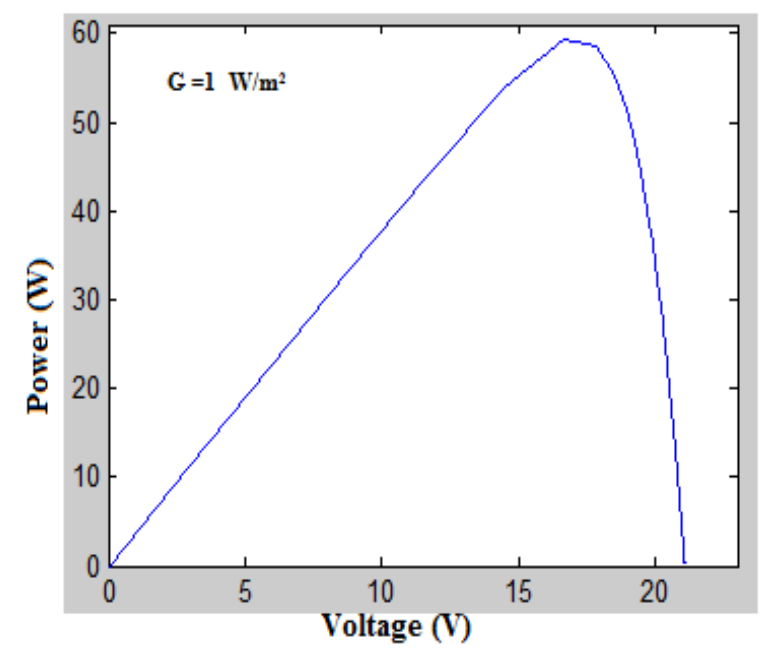

Figure 9: V-I Characteristics of a PV cell at $\mathrm{G}=1 \mathrm{~W} / \mathrm{m}^{2}$

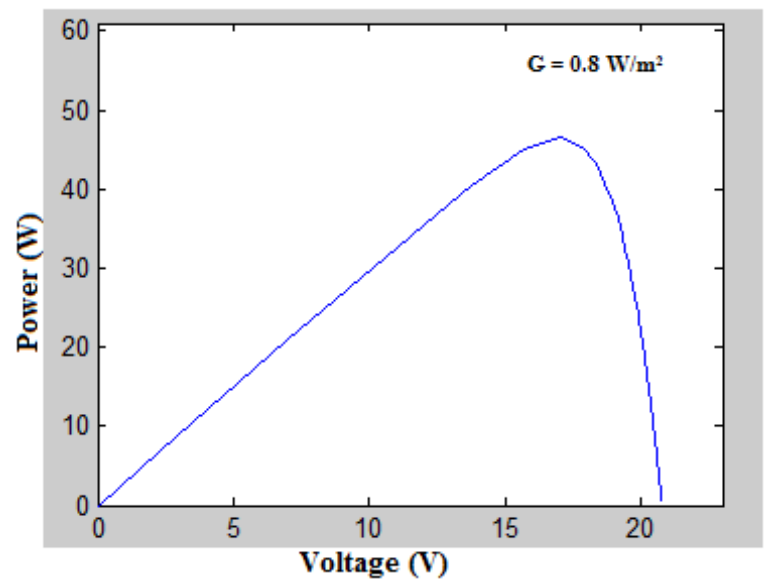

Figure 10: P-V Characteristics of a PV cell at $G=1 \mathrm{~W} / \mathrm{m}^{2}$

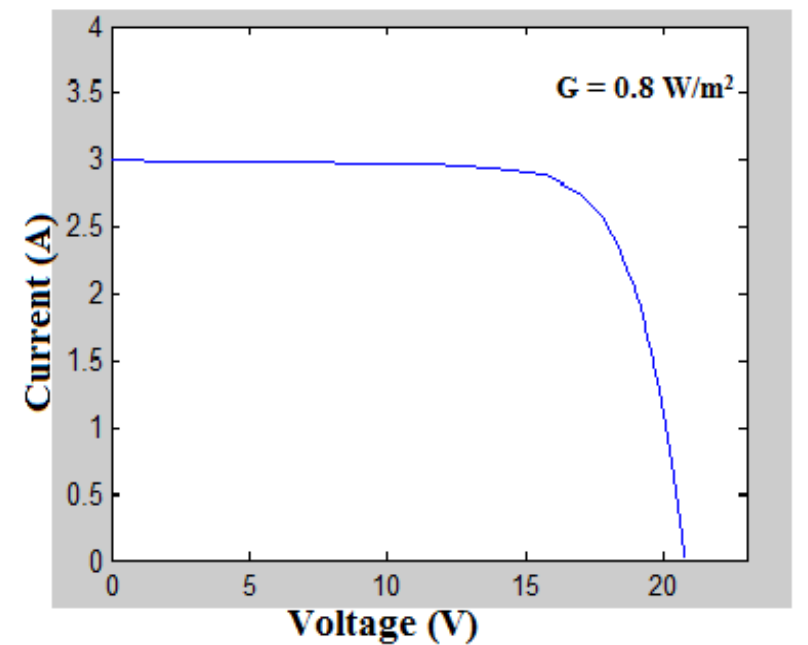

Figure 11: V-I Characteristics of a PV cell at $\mathrm{G}=0.8 \mathrm{~W} / \mathrm{m}^{2}$

The modelling and simulation has been done in Simulink software available with MATLAB. In this work Simulation was carried out, for different values of isolations $(G) \mathrm{W} / \mathrm{m}^{2}$ with constant temperature $=25^{\circ} \mathrm{C}$. In this paper a mathematical model of a PV cell, implemented in Matlab-Simulink environment has been proposed.

Table 1: Voltage, current and power values related to different radiation.

\begin{tabular}{|c|c|c|c|c|}
\hline Sr. No. & $\mathrm{G}\left(\mathrm{KW} / \mathrm{m}^{2}\right)$ & Voltage & Current $(\mathrm{A})$ & Power $(\mathrm{W})$ \\
\hline 1 & 1 & 21.04 & 3.8 & 59 \\
\hline 2 & 0.8 & 21 & 3 & 48 \\
\hline 3 & 0.6 & 20.4 & 2.3 & 35 \\
\hline 4 & 0.5 & 20.2 & 1.9 & 30 \\
\hline 5 & 0.4 & 19.89 & 1.5 & 25 \\
\hline
\end{tabular}

Finally it is concluding that photovoltaic current vary directly w. r. t variation in solar radiation, whereas PV module voltage slightly changes. The result is tabulated in Table 1.It is seen that it current is directly proportional to the radiation while voltage remains unaffected.

\section{Reconfiguration}

There is one more way to optimize power from the mismatched PV array. In this technique PV modules/cells in a PV array are continuously rearranged in series or parallel connections to facilitate the PV system to deliver maximum power and work more as a constant power source even in shading conditions. An algorithm is designed to ensure that these cells/modules will adaptively reconfigure the solar array connections in real time to track the maximum power output. Though this method increases the power output for mismatch conditions the implementation of this method on PV array of significant capacity (few $\mathrm{kW}$ to $\mathrm{MW}$ ) is not so practical[1] [2].

\section{Fuzzy Logic Control Based MPPT}

\section{A) MPPT}

To automatically find the voltage $\left(\mathrm{V}_{\mathrm{MPP}}\right)$ or current $\left(\mathrm{I}_{\mathrm{MPP}}\right)$ at which a PV array should operate to obtain the maximum power output $\left(\mathrm{P}_{\mathrm{MPP}}\right)$ under a given temperature and irradiance. Partial shading conditions it is possible to have multiple local 


\section{International Journal of Science and Research (IJSR) \\ ISSN (Online): 2319-7064 \\ Index Copernicus Value (2015): 78.96 | Impact Factor (2015): 6.391}

maxima, but overall there is still only one true MPP. To find the exact MPP there are many conventional techniques viz. Hill Climbing Algorithm, Incremental Conductance, Fractional Open-Circuit Voltage, Fractional Short-Circuit Current etc [4] [5].

\section{B) Fuzzy Logic Control System}

Due to developments in micro controller and DSP technologies, fuzzy logic control has received increased interest in MPPT applications. Fuzzy logic controllers have the advantages of working on systems with nonlinearities, not needing an accurate dynamic model and working with imprecise inputs. The concept of the control system can be explained by Fig.12. The objective of the system is to push the operating point towards the point Pmax using controller. The advantage of fuzzy control is that it is robust, fast and responds instantaneously to atmospheric changes. The inputs to the fuzzy logic system will be error $(E)$ and Change in Error $(\Delta E)$. The output will be the Change in Duty Cycle $(\Delta \mathrm{D})$ at sampling instant $\mathrm{n}$. The fuzzy logic control MPPT is as shown in figure 12. MPPT Using Fuzzy Logic consists of mainly two components viz. DC-DC converter and fuzzy logic control system.

A DC/DC converter serves the purpose of transferring maximum power from the solar PV cell to the load. A DC/DC converter acts as an interface between the load and the PV cell. By changing the duty cycle, the load impedance is varied and matched at the point of the peak power with the source, so as to transfer the maximum power [13]. There are four basic topologies for DC/DC converter: Buck, Boost, Buck-Boost and Cuk.

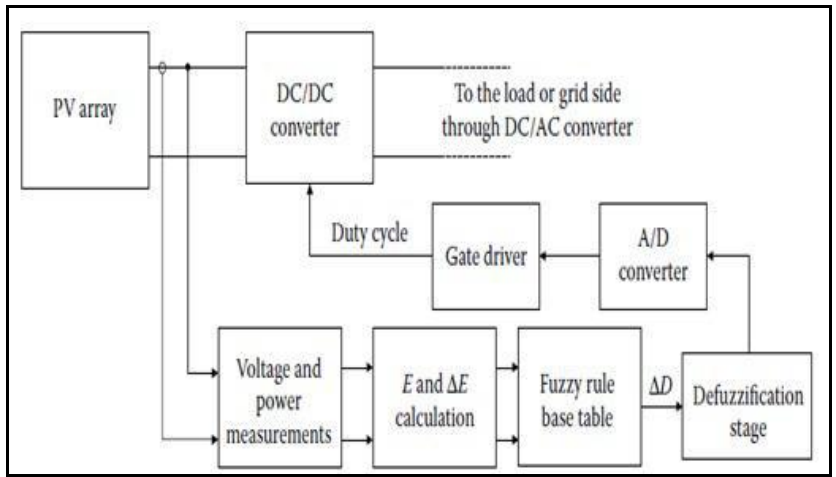

Figure12: Block diagram of fuzzy logic control based MPPT

The advantage of fuzzy control is that it is robust, fast and responds instantaneously to atmospheric changes. The inputs to the fuzzy logic system will be error (E) and Change in Error $(\Delta \mathrm{E})$. The output will be the Change in Duty Cycle $(\Delta \mathrm{D})$ at sampling instant $\mathrm{n}$. The fuzzy logic consists of the following stages: Fuzzification, rule base, inference system and defuzzifcation.

The Fuzzification stage converts input variables into linguistic variables based on a membership function as shown in Figure 13. In this case, there are seven fuzzy levels, which are NB (Negative Big),NM(Negative Medium), NS (Negative Small),ZE(zero),PS(Positive Small), PM(Positive Medium), and PB (Positive Big).As number of fuzzy levels increases, the accuracy. In the membership function, some specific fuzzy levels can be designed as unsymmetrical to make them more dominant, in other words to give them more importance. The error $\mathrm{E}$ and its variation $(\Delta \mathrm{E})$ are inputs to the fuzzy logic-based MPPT controller. $\mathrm{E}$ and $\Delta \mathrm{E}$ can be calculated based on the user"s preferences.

$\mathrm{P}(\mathrm{n})=\mathrm{V}(\mathrm{n}) \times \mathrm{I}(\mathrm{n})$

$$
E(n)=\frac{P(n)-P(n-1)}{V(n)-V(n-1)}
$$

$$
\Delta \mathrm{E}=\mathrm{E}(\mathrm{n})-\mathrm{E}(\mathrm{n}-1)
$$

The memberships functions associated with the fuzzy controller is given in figure 13 .

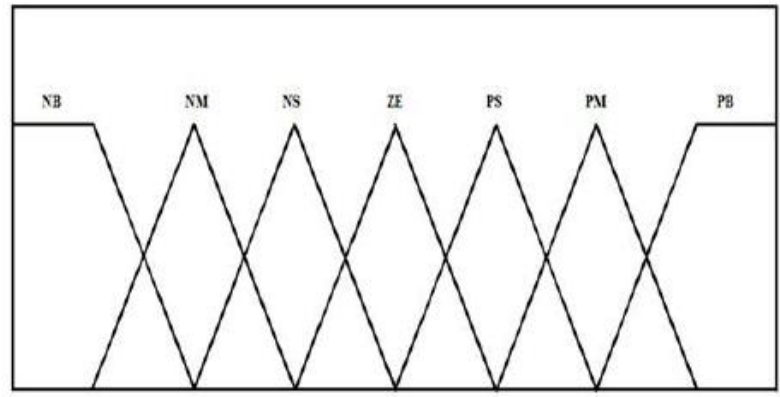

Figure 13: Membership Function

Generally, the output of the fuzzy logic controller is the change in duty ratio $\mathrm{D}$ of the power converter. This change in the duty ratio can be calculated and converted to the linguistic variables. Different combinations of the error, E, and its variations $\Delta \mathrm{E}$, can be used as the linguistic variables assigned to D. For a boost converter, Table 2 can be used for this purpose. For example, if the operating point is far to the right of the MPP, and $\mathrm{E}$ is NB and $\mathrm{E}$ is $\mathrm{ZE}$, then a large decrease is required in the duty ratio to decrease the voltage, that is $D$ should be NB to reach the MPP. The fuzzy logic controller output is converted from a linguistic variable to a numerical variable using a membership function as shown in figure (13) in the defuzzifcation stage. By defuzzifcation, the controller produces an analog output signal, which can be converted to a digital signal and controls the power converter of the MPPT system. Voltage and power are measured to calculate E and $\Delta \mathrm{E}$. Then, these values are evaluated by a fuzzy rule base table similar to Table 2 . The output of the fuzzy rule base table is the required change in duty cycle. In the defuzzifcation stage, the numerical value of the duty cycle is determined via the conversion from linguistic values. Finally, through an analog to digital $(\mathrm{A} / \mathrm{D})$ converter and a gate driver, the necessary switching signal is applied to the power converter of the MPPT. Under varying atmospheric conditions, the fuzzy logic controllers show good performance in MPPT applications. On the other hand, the effectiveness of the fuzzy logic controller depends on the accuracy of the calculation of error and its variations and the rule base table developed by the user. For better efficiency, the membership functions and rule base table can be continuously updated or tuned to achieve the optimum performance similar to an adaptive fuzzy logic controller. In this way, fast convergence to the MPP and minimal fluctuation around MPP can be achieved. In addition, the tracking performance depends on the type of membership function. 


\section{International Journal of Science and Research (IJSR) \\ ISSN (Online): 2319-7064 \\ Index Copernicus Value (2015): 78.96 Impact Factor (2015): 6.391}

Figures 13 and 14 shows the membership functions of input $\mathrm{E}$ and $\Delta \mathrm{E}$ respectively [11][12].

Table 2: Gives the rules of the FLC

\begin{tabular}{|c|c|c|c|c|c|c|c|}
\hline $\mathrm{E} / \Delta \mathrm{E}$ & $\mathrm{NB}$ & $\mathrm{NM}$ & $\mathrm{NS}$ & ZE & PS & PM & PB \\
\hline NB & NB & NB & NB & NB & NM & NS & ZE \\
\hline NM & NB & NB & ND & NM & NS & ZE & PS \\
\hline NS & NB & NB & NM & NS & ZE & PS & PM \\
\hline ZE & NB & NM & NS & ZE & PS & PM & PB \\
\hline PS & NM & NS & ZE & PS & PM & PB & PB \\
\hline PM & NS & ZE & PS & PM & PB & PB & PB \\
\hline PB & ZE & PS & PM & PB & PB & PB & PB \\
\hline
\end{tabular}

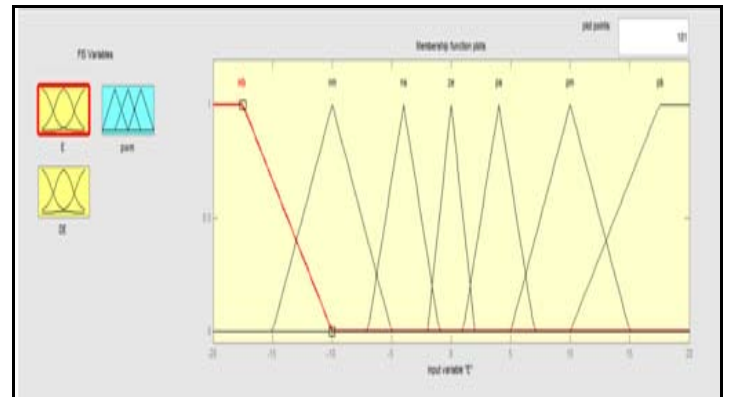

Figure 14: Shows the membership functions of input $\mathrm{E}$

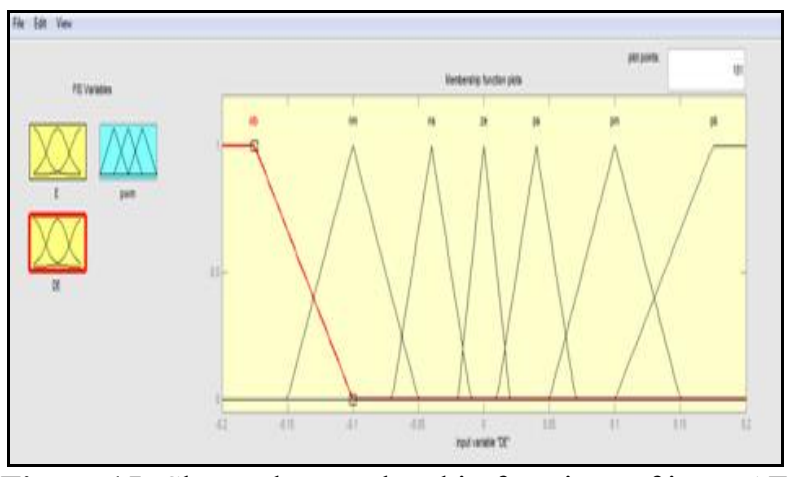

Figure 15: Shows the membership functions of input $\Delta \mathrm{E}$

\section{Grid Connected System}

In grid connected system, the system voltage should synchronise with the grid voltage. For this purpose the inverter should work in the grid frequency and voltage. The control scheme of grid connected inverter consisting of three parts. Direct and quadrature axis current reference generator, PLL and $\mathrm{d}-\mathrm{q}$ frame generation of grid voltage and current, Conversion voltage generation, PWM reference generation, Sine PWM with third harmonic injection for switching the inverter[11] [12] [13].

1)Id-Iq reference generation is shown in figure 11. The dc link voltage feedback and reference dc voltage are given to Id-Iq reference generator. After making per unit the error signal is given to PI controller to produce $\mathrm{d}$ axis reference. The $\mathrm{q}$ axis component is set to be zero.

2) The grid voltage and current are given to a discrete three phase PLL to produce wt reference and using Park's transformation current and voltage abc are converted to $\mathrm{d}-\mathrm{q}-\mathrm{o}$ components as shown in figure 12 .

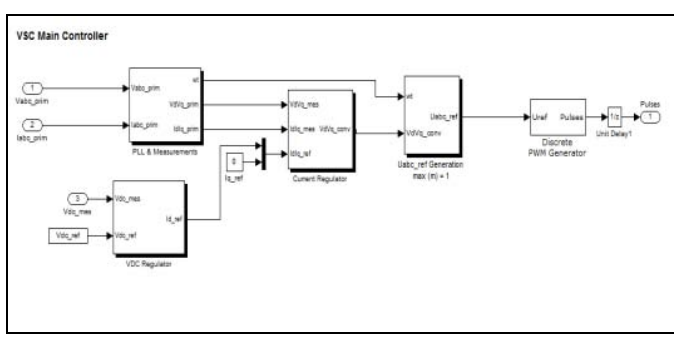

Figure 16: PLL and grid reference generator

3)From the generated dq current reference and measured grid voltage and current dq reference, the conversion voltage is calculated. The Simulink model of conversion voltage generation is given below based on the equations 9 and 10 .

$$
\begin{aligned}
& \mathrm{V}_{\mathrm{d}_{-} \text {conv }}=\mathrm{V}_{\mathrm{dmes}}+\mathrm{I}_{\mathrm{d}} * \mathrm{R}-\mathrm{I}_{\mathrm{q}} * \mathrm{~L} \\
& \mathrm{~V}_{\mathrm{q} \text { conv }}=\mathrm{V}_{\mathrm{qmes}}+\mathrm{I}_{\mathrm{d}} * \mathrm{~L}-\mathrm{I}_{\mathrm{q}} * \mathrm{R}
\end{aligned}
$$

4) The reference sinusoidal signals are given to third harmonic injection block to produce third harmonic injected sinusoidal signals. This signal is subjected to pwm generation and the six switching pulses are given to the inverter. The $\mathrm{DC} / \mathrm{AC}$ Inverter is used to regulate the output voltage of $\mathrm{DC} / \mathrm{DC}$ converter and connects the $\mathrm{PV}$ cell with $\mathrm{DC} / \mathrm{DC}$ converter to the grid. The output voltage is required to be sinusoidal and in phase with the grid voltage.. The overall simulink model of grid connected PV system with fuzzy logic control based MPPT is given in figure 17. This model includes PV array, dc-dc converter, fuzzy logic control based MPPT, inverter, P-Q control scheme for inverter, LC filter, circuit breaker, local loads, grid and measuring system [13].

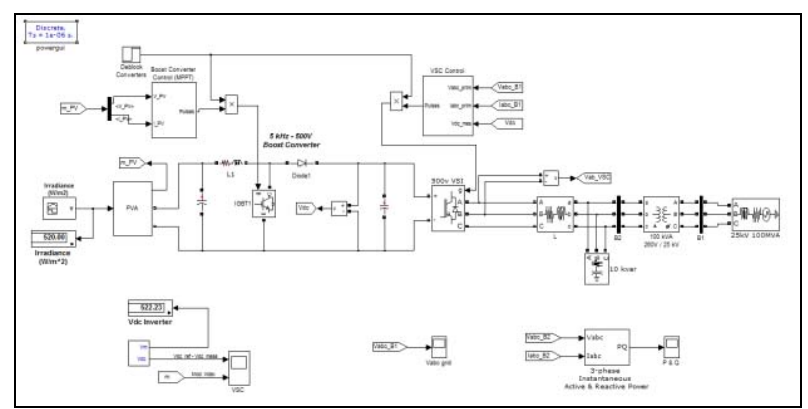

Figure 17: Simulink Model of grid connected PV System

\section{Simulation Results}

Figure 18 shows the active and reactive power obtained from the PV system. The active and reactive powers can be controlled independently by this P-Q control scheme.

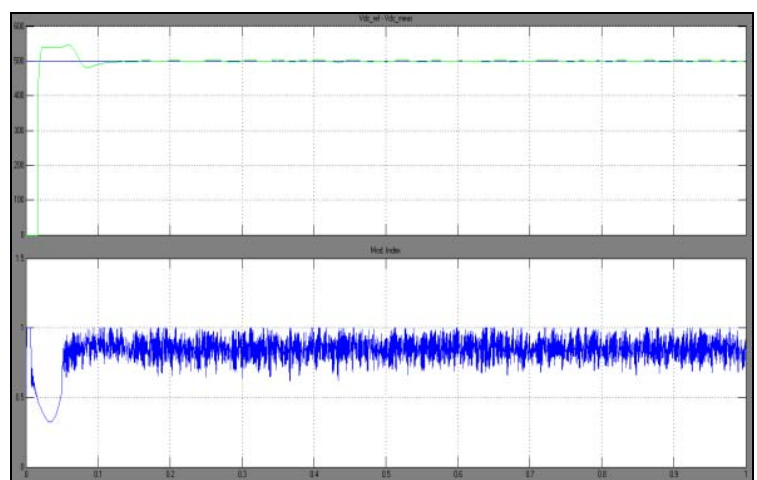

Figure 18: Shows the P and Q obtained from the PV system 


\section{International Journal of Science and Research (IJSR) \\ ISSN (Online): 2319-7064}

Index Copernicus Value (2015): 78.96 Impact Factor (2015): 6.391

The simulation result of grid connected PV system is given in figure 20. Voltage and current of grid connected PV system are given. THD analysis of the output voltage of grid connected PV system is given in figure 19. From the THD analysis it is clear that the total harmonic distortion is very less $(2.08 \%)$.

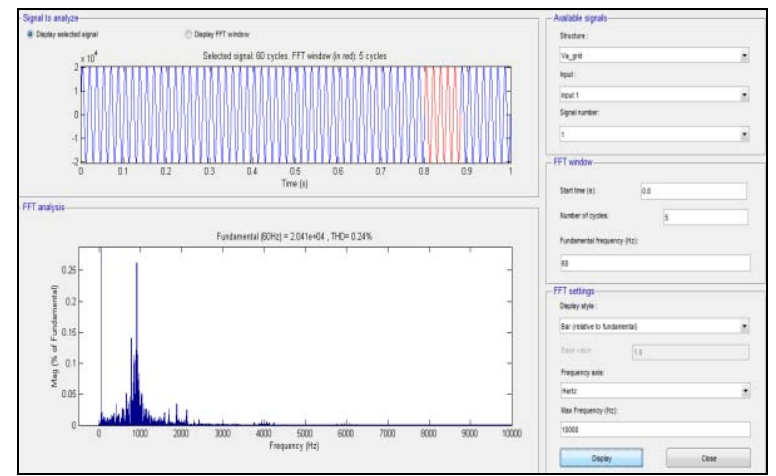

Figure 19: THD analysis of the output voltage of grid connected PV system.

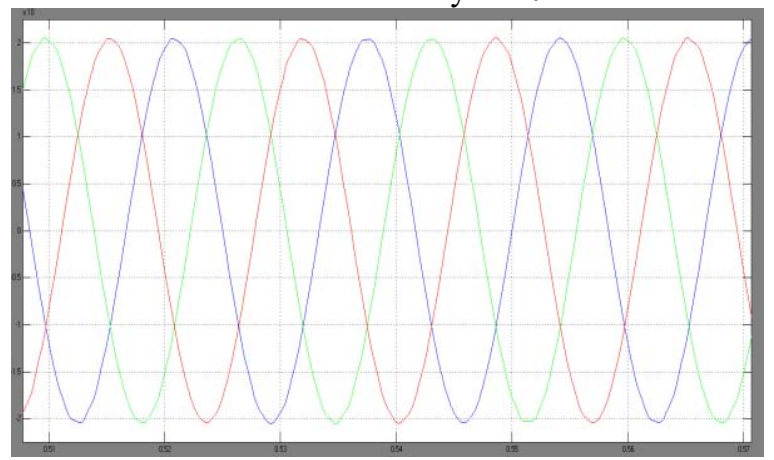

Figure 20: Output waveforms of the inverter.

\section{Conclusion}

The paper presents an overview of operation of PV cell under different environmental conditions and suggests a "Reconfiguration" technique to extract the maximum power from mismatched photovoltaic array. Also it present a fuzzy logic control based maximum power point tracking scheme for grid connected PV system to achieve maximum power. Fuzzy controlled MPPT strategy is used for PV output voltage to achieve closed loop control which can smoothly and quickly track the maximum power point of PV array. Grid connected PV systems are modeled and simulated. P-Q based control scheme provides fast closed loop control. The PV system generated a sinusoidal voltage having THD less than 3\%. P-Q control scheme provide exact synchronization of photovoltaic system with the utility grid. Also the P-Q control scheme provides independent active and reactive power control.

\section{References}

[1] A Mathematical Model to Determine the Electrical Energy Production in Photovoltaic Fields Under Mismatch Effect V. Di Dio , D. La Cascia, R. Miceli Member IEEE, C. Rando

[2] Reconfiguration strategy for optimization of solar photovoltaic array under non-uniform illumination conditions B.Patnaik1, P.Sharma1, E.Trimurthulu1,
S.P.Duttaguptal and V.Agarwal Department of Electrical Engineering, IIT-Bombay, Mumbai, India.

[3] A New Technique for Photovoltaic Module Performance Mathematical Model2010 International Conference on Chemistry and Chemical Engineering (ICCCE 2010).

[4] Comparison of Photovoltaic Array Maximum Power Point Tracking Techniques Trishan Esram. Student Member, IEEE, and Patrick L. Chapman, Senior Member, IEEE

[5] A New Voltage Equalization Based Distributed Maximum Power Point Extraction from a PV Source Operating Under Partially Shaded Conditions Nataraj Pragallapati, Pooja Sharma, Vivek Agarwal, Senior member, IEEE Indian Institute of Technology Bombay, Maharashtra, India

[6] January 01, 2008 Modeling and reconfiguration of solar photovoltaic arrays under non-uniform shadow conditions Dung Duc Nguyen Northeastern University

[7] Simulink based modeling, simulation and Performance Evaluation of an MPPT for maximum power generation on resistive load. 2011 2nd International Conference on Environmental Science and Technology PCBEE vol.6 (2011) C (2011) IACSIT Press, Singapore

[8] ,International energy outlook http://www.eia.gov/oial/aeo/tablebrowser/\#release=IEO2 013\&subject $=4-$ IEO2013\&table $=16$-IEO2013\&region $=$ 0-0\&cases $=$ Reference-d04 1117

[9] The Physics of the Solar Cell Jeffery L. Gray Purdue University, West Lafayette, Indiana, USA

[10] An Improvement on Empirical Modelling of Photovoltaic Cells Dorin Petreuş1), Ionuț Ciocan1), and Cristian Fărca Technical University of Cluj-Napoca Faculty of Electronics, Telecommunications and Information Technology, 26-28 G. Bariţiu Street, Cluj-Napoca, Romania, Dorin.Petreuș@ael.utcluj.ro

[11] Design and Simulation of Grid Connected PV system Using Multilevel Inverters Design and Simulation of Grid Connected PV system Using Multilevel Inverters International Journal of Electrical and Electronics Engineering (IJEEE), ISSN (PRINT): 2231 - 5184, Volume-4, Issue-2, 2013.

[12]"Implementation of Single Phase Grid Tied Photovoltaic System by Employing Embedded Controller", S Sabarinathan, J. Mohammed, Shajahan, R. Ram Kumar. ISSN (Print): 2278-8948, Volume-2, Issue-5, 2013.

[13]"Grid Connected Photovoltaic System with Fuzzy Logic Control Based MPPT", has been proposed by Prince Jose, Priya Rani Jose. International Journal of Engineering and Innovative Technology (IJEIT). 